\title{
Short Communication: Metabolic Syndrome and Adaptogenic Nutritional Supplement "AdMax"
}

\author{
A.G. Antoshechkin*
}

2180 Calumet Street, Clearwater, FL 33765, USA

\begin{abstract}
Metabolic syndrome manifestations include chronic fatigue, insulin resistance, elevated levels of glucose, lipids and cholesterol in the blood, and overweight. The main targets of nutritional supplement "AdMax" are the activation of energy metabolism and stress counteraction. In addition, the "AdMax" constituents decrease the concentration of blood glucose, enhance glucose utilization by cells, decrease the activity of triglyceride lipase and lower blood cholesterol levels. Comparison of metabolic syndrome manifestations to the activities of "AdMax" constituents argues that "AdMax" can be used as a preventive and treatment remedy for metabolic syndrome.
\end{abstract}

Keywords: Metabolic syndrome, Adaptogenic plants, Nutritional supplement "AdMax", "AdMax" properties, Prevention of Metabolic syndrome.

Metabolic syndrome is manifested by a number of deviations from the norm including chronic fatigue, insulin resistance, increased levels of glucose, lipids and cholesterol in the blood, and overweight. Prevalence of metabolic syndrome in the US adult population is close to $34 \%$ and increases with age [1]. Metabolic syndrome is a strong risk factor for coronary artery disease, stroke, and type 2 diabetes.

Biochemical mechanisms of metabolic syndrome are only partly elucidated. Insulin is a mediator that regulates glucose entry into cells from the blood. Insulin resistance prevents the glucose uptake evoking energy insufficiency in body cells, especially in brain neurons. As a result, the feeling of physical and mental fatigue arises. Body compensates the energy insufficiency by the activation of lipid metabolism, which results in increased concentrations of lipids and cholesterol in the blood. Overweight is also a consequence of energy deficit and alteration of lipid metabolism. Because glucose utilization by body cells is limited, its levels in the blood become elevated. The fact that multiple manifestations of metabolic syndrome are commonly observed in the same individual suggests that metabolic disturbances that underlie the syndrome are interconnected. One of the important factors that contribute to the development of metabolic syndrome is chronic stress [2, 3].

Nutritional supplement "AdMax" is a proprietary extract blend of adaptogenic plants: Leuzea carthamoides, Rhodiola rosea, Eleutherococcus senticosus and Schizandra chinensis [4]. The main targets of "AdMax" constituents are the activation of

*Address correspondence to this author at the 2180 Calumet Street, Clearwater, FL 33765, USA; E-mail: antoshechkin@earthlink.net energy metabolism [5-10] and stress counteraction [4]. In addition, "AdMax" constituents decrease concentration of blood glucose [11-13], enhance glucose utilization by cells [14], decrease activity of triglyceride lipase [15], and lower blood cholesterol levels [16].

Comparison of metabolic syndrome manifestations to the "AdMax" properties described above argues that "AdMax" can be used as a preventive and treatment remedy for metabolic syndrome.

Adaptogenic nutritional supplement "AdMax" was developed by Genext Research, Inc., FL 33765, USA and is manufactured by Nulab, Inc., FL 33765 (www.nulabinc.com).

\section{REFERENCES}

[1] Ford ES, Giles WH, Dietz, WH. Prevalence of metabolic syndrome among US adults: findings from the third National Health and Nutrition Examination Survey. JAMA 2002; 287: 356-9.

http://dx.doi.org/10.1001/jama.287.3.356

[2] Gohill BC, et al. Hypothalamic-pituitary-adrenal axis function and the metabolic syndrome X of obesity. CNS Spectr 2001; 6: 581-6.

[3] Tsigos C, Chrousos GP. Hypothalamic-pituitary-adrenal axis, neuroendocrine factors and stress. J Psychosom Res 2002; 53: 865-71. http://dx.doi.org/10.1016/S0022-3999(02)00429-4

[4] Antoshechkin AG. Adaptogens and Health Care. AuthorHouse Book Publishing Compsny, Bloomington, III, 2005.

[5] Saratikov AS, Tusov SF. Influence of Leuzea carhtamoides on physical performance and some functional tests of the organism. Isv SO AN SSSR, Ser Biol 1963; 12: 126-32.

[6] Asano K, et al. Effect of Eleutherococcus senticosus extract on human physical working capacity. Planta Med 1986; 48 : 175-7.

http://dx.doi.org/10.1055/s-2007-969114

[7] De Bock K, et al. Acute Rhodiola rosea intake can improve endurance exercise performance. Int $\mathrm{J}$ Sport Nutr Exerc Metab 2004; 14: 298-307. 
[8] Li HB, et al. Salidroside stimulated glucose uptake in skeletal muscle cells by activating AMP-activated protein kinase. Eur J Pharmacol 2008; 588: 165-9. http://dx.doi.org/10.1016/j.ejphar.2008.04.036

[9] Lee FT, et al. Chronic Rhodiola rosea extract supplementation enforces exhaustive swimming tolerance. Am J Chin Med 2009; 37: 557-72.

http://dx.doi.org/10.1142/S0192415X09007053

[10] Antoshechkin A, et al. Stimulating effect of the plant extract complex "AdMax" on expression level of the gene involved in energy metabolism in cultured human fibroblasts. Recent Progress in Medicinal Plants, Sigh VK \& Govil JN, eds. Studium Press, Houston, TX, 2009; Vol. 25: pp. 15-19.

[11] Yoshida $T$, et al. Effect of ecdysterone on hyperglycemia in experimental animals. Biochem Pharmacol 1971; 20: 3263-8. http://dx.doi.org/10.1016/0006-2952(71)90431-X

[12] Hikino $\mathrm{H}$, et al. Isolation and hypoglycemic activity of eleutherans A, B, C, D, E, F, and G: glycans of Eleutherococcus senticosus roots. J Nat Prod 1986; 49: 293-7. http://dx.doi.org/10.1021/np50044a015
[13] Niu HS, et al. Hypoglycemic effect of syringin from Eleutherococcus senticosus in streptozotocin-induced diabetic rats. Planta Med 2008; 74: 109-13. http://dx.doi.org/10.1055/s-2008-1034275

[14] Li HB, et al. Salidroside stimulated glucose uptake in skeletal muscle cells by activating AMP-activated protein kinase. Eur J Pharmacol 2008; 588: 165-9. http://dx.doi.org/10.1016/j.ejphar.2008.04.036

[15] Catalan RE, et al. Alterations in rat lipid metabolism following ecdysterone treatment. Comp Biochem Physiol 1985; 81b: 771-5.

http://dx.doi.org/10.1016/0305-0491(85)90403-1

[16] Lupien PJ, Hinse C, Chaudhary KD. Ecdysterone as a hypoholesterolemic agent. Arch Int Physiol Biochim 1969; 77: 206-12.

http://dx.doi.org/10.3109/13813456909109700 